\title{
PERAN PEREMPUAN (IBU) DALAM MENDIDIK ANAK
}

\section{Deviwanti Santi Pakiding}

\author{
Institut Agama Kristen Negeri Toraja \\ santipakiding12@gmail.com
}

1. Abstrak : Jurnal ini berisi tentang peran Perempuan (Ibu) dalam mendidik Anak. Lakilaki dan perempuan berbeda tugasnya. Seorang Perempuan memiliki keistimewaan, dia bisa mengerjakan tugas dan tanggung jawabnya walaupun memiliki anak-anak yang masih bayi. Terkhususnya, keistimewaan Perempuan sebagai Ibu adalah dia bisa mengandung dan melahirkan seorang anak. Ini yang membedakan Perempuan dengan laki-laki. Dan hal ini jugalah yang memungkinkan dan tidak bisa diragukan lagi bahwa seorang Perempuan sebagai Ibu dapat mendidik Anak.

Kata Kunci : Perempuan, Peran, Pendidikan Anak

\section{Pendahuluan}

Peran adalah serangkaian perilaku seseorang yang diharapkan pada seseorang sesuai dengan posisi sosial yang diberikan baik secara formal maupun informal. Wanita memiliki peran yang amat besar dalam kehidupan bermasyarakat. Perempuan yang juga sebagai ibu harus memikirkan tanggung jawabnya dalam berumah tangga. Seorang ibu melakukan segala pekerjaan rumah, dan juga mengawasi, memperhatikan dan mendampingi anak-anaknya dalam pembentukan karakter dan watak si anak serta pendidikan anak. Sejak anak terlahir hingga dewasa dengan pengawasan orang tuanya, dibesarkan dan di didik serta dibimbing oleh keluarga. Hubungan anak dengan orang tua merupakan hubungan pertama oleh si anak. Sikap, cara pengasuhan, pendidikan yang diberikan oleh orang tua kepada anak sangat berpengaruh secara langsung.

\section{Tujuan dan Manfaat}


Tujuan dari Jurnal ini adalah diharapkan derajat perempuan-perempuan diangkat, karena saya melihat sekarang ini banyak orang yang menganggap pekerjaan Perempuan itu hanya bisanya di dapur saja, namun orang-orang lain tidak tahu bahwa Perempuan sebagai ibu dalam kesibukannya melakukan pekerjaan rumahnya juga mampu mendidik anak-anak dengan baik.

Manfaat dari Jurnal ini adalah memberikan dorongan dan pemahaman kepada perempuan-perempuan diluaran sana agar melakukan tugas dan kewajibannya dan mampu mendidik anak dengan baik.

\section{Pembahasan}

Laki-laki diberi tanggung jawab sebagai pencari nafkah dengan mengelolah bumi (Kej. 3:17), sedang perempuan akan melahirkan dan mengasuh anak. Implikasinya secara praktis ialah laki-laki dianggap lebih kuat dan lebih penting daripada perempuan dalam segala hal. Laki-laki dominan di bidang publik, sementara perempuan didomestifikasi ${ }^{1}$. Memang benar bahwa dalam Kitab Kejadian laki-laki diberi tanggung jawab untuk mencari nafkah. Secara Fisik laki-laki lebih kuat daripada perempuan. Saya seringkali melihat teman-teman saya mengatakan bahwa mengapa laki-laki itu dianggap spesial, mengapa mereka lebih dianggap daripada perempuan, seakan-akan ada pembedaan yang sangat menonjol antara laki-laki dan perempuan. Ketika laki-laki bersekolah maka orangorang sekelilingnya akan mendukung bahkan menyemangati agar mencapai cita-cita setinggi langit. Namun, tidak sama dengan perempuan ketika ingin bersekolah atau melanjutkan pendidikannya di perguruan tinggi maka pasti tidak sedikit yang merendahkan dan mengatakan ngapai sekolah tinggi-tinggi toh juga nantinya akan kerja di dapur. Kadang juga saya lihat baik di media sosial atau secara langsung ketika sudah berkeluarga maka seenaknya suami berlaku kasar terhadap istri, merendahkan istrinya dan juga mengatakan kepada istrinya bahwa ia hanya di rumah tidak melakukan sesuatu apapun namun secara tidak sadar Perempuan sebagai ibu itu melakukan banyak sekali pekerjaan dirumah. Kita juga dapat melihat keadaan yang sekarang seperti berbanding terbalik. Perempuan-perempuan sekarang banyak yang jadi wanita karir walaupun sudah berkeluarga, mereka dengan tekun mengurus pekerjaan rumah ketika tidak bekerja diluar atau tidak sibuk, tidak melupakan tugasnya dalam mengurus anak dan mendidik anak.

1 Rannu Sanderan, “Jabatan Gerejawi dan Peran Perempuan dalam Pelayanan Gerejawi”, Kaum Perempuan dan Jabatan Gerejawi : 2 
Banyak sekarang yang saya lihat termasuk di sekitaran saya perempuan lebih banyak bekerja dan menghasilkan uang daripada laki-laki. Hal ini dikarenakan karena mungkin laki-laki sebagai suami tidak mendapatkan pekerjaan namun si perempuan sebagai ibu memiliki pekerjaan.

Anak-anak melihat bagaimana orangtuanya berperilaku selanjutnya meniru lanjut perilaku tersebut. Peniruan dalam tulisan ini, diberi makna positif pada peniruan sebagai salah satu proses belajar dalam totalitas kehidupan anak, baik di sekolah, di rumah, persekutuan di gereja, hingga interaksi sosialnya ${ }^{2}$. Ketika dalam keluarga anak itu penting sekali diberikan pendidikan. Seringkali kita mendengarkan perkataan orang yang mengatakan bahwa pendidikan utama bagi seorang anak itu berasal dari keluarga. Oleh sebab itu selaku orang tua mampu mendidik anak dengan sebaik mungkin. Dan peran mendidik anak yang paling utama adalah seorang ibu. Seorang Ibu bukan hanya mengandung dan melahirkan saja, namun ia harus mendidik anaknya yang tentu saja mendidik anak itu butuh waktu yang cukup lama dan pastinya mengelurkan banyak tenaga. Walaupun dalam keluarga suami tidak kalah pentingnya, namun ibulah yang memiliki peran yang sangat besar. Anak-anak dapat mencontoh perilaku orang tuanya baik yang positif maupun yang negatif. Walaupun sifat itu tidak diturunkan namun karena melihat, maka anak-anak juga akan mencontoh sifat orang tuanya.

Orangtua diberi tanggungjawab mendidik dan otoritas korektif terhadap anaknya, serta seyogianya memberi latihan-latihan pada waktu yang tepat. Menurut Amsal Salomo, kebencian orangtua pada anak terlihat pada pembiaran yang tidak memberi koreksi terhadap kesalahan anak. (bandingkan kisah Eli dan kedua anaknya) ${ }^{3}$. Sungguh besar tanggungjawab yang dipikul oleh orang tua karena mereka harus menjaga, mendidik anak-anak yang telah dipercayakan kepada mereka. Sebuas-buasnya harimau tetap ia tidak akan memakan anaknya sendiri. Begitupun juga dengan orang tua tidak ada orang tua yang membenci anaknya, menelantarkan anaknya bahkan membuang anaknya. Orang tua pasti sayang kepada anak-anaknya.

2 Rannu Sanderan, ”Exemplery Menemukenali Kunci Pendidikan Iman Bagi Anak dalam Keluarga dan Pembelajaran Agama di Sekolah”, 3 Jurnal PAK_Ganjil 2016_2017_Exemplary : 2

3 Rannu Sanderan, ”Disiplin Asketisme dan Harmoni Kontribusi Disiplin Diri Bagi Pengembangan Pendidikan Kristen 


\section{Kesimpulan dan Saran}

\section{a. Kesimpulan}

Laki-laki dan Perempuan mempunyai tugas yang berbeda, namun bukan berarti ada yang ditinggikan dan ada yang direndahkan. Laki-laki dan perempuan sama, mereka sama-sama mempunyai tanggung jawab dan hak yang sama. Perempuan sebagai Ibu memiliki peran yang amat penting dan yang utama dalam keluarga. Ia memiliki keistimewaan, dia bisa mengandung dan melahirkan generasi-generasi baru kedalam dunia ini. Walaupun ia sibuk dalam mengerjakan pekerjaan rumah yaitu membersihkan, memasak, mencuci dan lain-lain namun ia juga memiliki peran yang amat besar dalam mendidik anak-anak yang telah dipercayakan kepadanya. Laki-laki sebagai suami menopang istrinya bukan merendahkannya.

\section{b. Saran}

Setelah membaca Jurnal ini saya menyarankan kepada kita semua agar tidak memandang rendah tugas perempuan sebagai ibu dalam keluarga. Para suami-suami hargailah istrimu karena ia sangat berjasa dalam keluargamu. Dan juga kepada istri hormati suamimu karena dia telah lelah dan capek dalam mencari nafkah demi keluarga. Kepada orang tua tanpa terkecuali didiklah anak-anakmu dengan takut akan Tuhan, didiklah mereka menjadi pribadi yang bertanggung jawab, bentuklah watak dan sifat mereka menjadi baik, sehingga kelak menjadi sukses dan akan melakukan apa yang telah diajarkan oleh kedua orang tuanya kepada anak-anaknya kelak.

\section{Daftar Pustaka}


Sanderan, Rannu. "Jabatan Gerejawi dan Peran Perempuan dalam Pelayanan Gerejawi”, Kaum Perempuan dan Jabatan Gerejawi : 2

Sanderan, Rannu. "Exemplery Menemukenali Kunci Pendidikan Iman Bagi Anak dalam Keluarga dan Pembelajaran Agama di Sekolah", 3 Jurnal PAK_Ganjil 2016_2017_Exemplary : 2

Sanderan, Rannu.’Disiplin Asketisme dan Harmoni Kontribusi Disiplin Diri Bagi

Pengembangan Pendidikan Kristen 